\title{
Climate Change Scenarios and Their Implications on the Energy Performance of Hellenic Non-Residential Buildings
}

\author{
Kalliopi G. Droutsa ${ }^{1,2, *}$, Simon Kontoyiannidis ${ }^{1}$, Constantinos A. Balaras ${ }^{1}{ }^{\circledR}$, Athanassios A. Argiriou ${ }^{2}{ }^{\circledR}$, \\ Elena G. Dascalaki ${ }^{1}{ }^{(D}$, Konstantinos V. Varotsos ${ }^{3}$ and Christos Giannakopoulos ${ }^{3}(\mathbb{D}$ \\ 1 Group Energy Conservation, Institute for Environmental Research \& Sustainable Development, \\ National Observatory of Athens, 11810 Athens, Greece; skonto@noa.gr (S.K.); costas@noa.gr (C.A.B.); \\ edask@noa.gr (E.G.D.) \\ 2 Laboratory of Atmospheric Physics, Department of Physics, School of Science, University of Patras, \\ 26504 Patras, Greece; athanarg@upatras.gr \\ 3 Institute for Environmental Research \& Sustainable Development, National Observatory of Athens, \\ 11810 Athens, Greece; varotsos@noa.gr (K.V.V.); cgiannak@noa.gr (C.G.) \\ * Correspondence: pdroutsa@noa.gr; Tel.: +30-21-(0)810-9144
}

\section{check for} updates

Citation: Droutsa, K.G.; Kontoyiannidis, S.; Balaras, C.A.; Argiriou, A.A.; Dascalaki, E.G.; Varotsos, K.V.; Giannakopoulos, C. Climate Change Scenarios and Their Implications on the Energy Performance of Hellenic Non-Residential Buildings. Sustainability 2021, 13, 13005. https:/ / doi.org/10.3390/su132313005

Academic Editor: Andrei P. Kirilenko

Received: 27 September 2021

Accepted: 22 November 2021

Published: 24 November 2021

Publisher's Note: MDPI stays neutral with regard to jurisdictional claims in published maps and institutional affiliations.

Copyright: (c) 2021 by the authors. Licensee MDPI, Basel, Switzerland. This article is an open access article distributed under the terms and conditions of the Creative Commons Attribution (CC BY) license (https:/ / creativecommons.org/licenses/by/ $4.0 /)$.

\begin{abstract}
It is important to understand how the climate is changing in order to prepare for the future, adapt if necessary, and, most importantly, take proper precautionary measures to alleviate major negative impacts. This work investigates the potential impacts of climate change on the anticipated energy performance of the existing Hellenic building stock until the end of the century. The assessment considers average climatic projections for two future time periods, one for the near and one for the distant future, following two representative concentration pathways (RCPs). The first one is a baseline scenario (RCP8.5) representing the highest greenhouse gas emissions. The second is an intermediate stabilization scenario (RCP4.5), assuming the imposition of conservative emissions mitigation policies. The future climate data are generated for 62 cities throughout Greece. As a case study, the work focuses on Hellenic non-residential (NR) whole buildings, analyzing available data collected during about 2500 energy audits of real NR buildings. The available data are used to assess the buildings' heating and cooling demand and energy use. The annual average air temperature for Greece in 2050 is projected to increase by $1.5 \mathrm{~K}$ for the RCP4.5 scenario and by $1.9 \mathrm{~K}$ for the RCP8.5 scenario. In 2090, the increase is estimated to reach $1.7 \mathrm{~K}$ and $4.2 \mathrm{~K}$, respectively. Accordingly, if the existing NR buildings are not renovated, the average heating energy use is expected to decrease by $22-26 \%$ in 2050 and by $23-52 \%$ in 2090 . On the other hand, the average cooling energy use is expected to increase by $24-30 \%$ in 2050 and by $28-66 \%$ in 2090 .
\end{abstract}

Keywords: climate change; energy demand; energy use; non-residential buildings

\section{Introduction}

Earth's climate has warmed up and cooled down many times throughout human history [1]. However, the current warming trend is occurring at a faster rate mainly due to human activity ( $95 \%$ confidence) [2]. It is well-documented that the average surface temperature of our planet has risen by $1.2 \mathrm{~K}$ since the late 19th century, mainly due to increased carbon dioxide emissions into the atmosphere and other human-related activities [3]. In fact, the last three decades have been the warmest since 1850 [2]. Moreover, 2020 is the second warmest year on record [4], while the global surface temperature is projected to increase between $1.0 \mathrm{~K}$ and $3.7 \mathrm{~K}$ at the end of this century, depending on future greenhouse gas (GHG) emissions [5]. Apparently, these climate changes will potentially lead to both short- and long-term negative impacts on ecosystems, the built environment, and humans [2].

The building sector accounts for about one third of the global final energy, almost half of global electricity consumption, and about one third of global $\mathrm{CO}_{2}$ emissions [6]. In the 
European Union (EU-27), the energy use in buildings represents about $40 \%$ of the total final energy, which is allocated by $26.3 \%$ to residential buildings and $13.7 \%$ to non-residential (NR) buildings, varying widely among Member States [7].

As outdoor air temperature changes, the energy profiles of buildings will also change. Specifically, the heating and cooling demand of buildings are directly affected by climate change [8]. Global warming will lead to a lower heating demand during winter and a higher cooling demand during summer. Considering that the environmental impacts resulting from these two effects are not equivalent, it is not evident whether the net energy use for heating and cooling will increase or decrease. Although space cooling required only $15 \%$ of the energy used for heating around the world during 2019, the cooling demand of buildings is expected to grow at an annual rate of more than $3 \%$ for the next three decades, that is eight times faster than the demand for heating in the last 30 years [6]. Climate change will also alter the fuels used in buildings, with indirect impacts on building energy expenditures and $\mathrm{CO}_{2}$ emissions. Furthermore, a rise in the outdoor temperature will also affect indoor temperature, resulting in an increase in thermal discomfort conditions as a result of overheating, mainly during summer [9-11].

The impacts of climate change on the energy use in various types of buildings have attracted a lot of attention, and several studies have been performed throughout the world. In the United States, warm and mixed climate zones are expected to experience an increase in total primary energy use for cooling and heating by 2080, while cold zones will experience a reduction, although there will be variations among different types of buildings $[8,12,13]$. In South America, residential buildings will face a decrease in heating and an increase in cooling energy use, while the net energy consumption will increase [14-16]. Furthermore, the total energy use of Brazilian office buildings is expected to increase [15]. Other studies performed in sub-tropical and tropical climates have indicated an increase in cooling energy use followed by an increase in the net energy use [17-20]. In high efficiency office buildings located in the cold Chinese climate region, the reduction of heating energy use outweighs the increase of cooling energy use, resulting in a decrease in annual net energy use until 2080 [21]. For the mild temperate climate of Adelaide in Australia, which is dominated by space heating, it is estimated that the cooling demand of buildings will become more significant than heating [22]. Significant changes in the energy performance of residential buildings in Ghana, a sub-Saharan African country, are also anticipated, leading to an increase in cooling energy demand [23].

Europe is projected to experience a decrease in heating demand that is quantified by the heating degree days (HDD), especially in southern countries [24]. Specifically, the decrease in HDD by 2100 is estimated to reach up to $60 \%$ throughout southern Europe and up to $45 \%$ in northern Europe. In Mediterranean countries, the largest decrease in HDD is expected to occur along the zone of northern Italy, the Balkans, Greece and Turkey. On the other hand, the cooling degree days (CDD), which relate to the cooling demand, are projected to increase by $100 \%$ in southern Europe and by $300 \%$ in central and eastern Europe by the end of the 21st century [24]. In particular, the increase in CDD is about $40 \%$ greater than the corresponding decrease in HDD for Spain, southern Italy, Greece, and Turkey. Most urban areas in Greece will experience a decline in HDD in winter and an increase in CDD in summer. Specifically, it is expected that there will be 15 fewer days per year that will require heating in all areas, while 5-20 additional days per year will require cooling [25].

Nowadays, the energy consumption for space heating in most European countries is greater than the energy use for space cooling by about 17 times [26]. However, most European buildings will experience a decrease in heating demand and an increase in cooling demand [27-30]. Over time, the heating demand is expected to show a downward trend from $5 \%$ in Nordic countries, to $16 \%$ in central regions, and up to $19 \%$ in southern counties. On the other hand, the cooling demand will progressively increase from $10 \%$ in southern countries, to $28 \%$ in central regions, and up to $44 \%$ in northern regions [31]. Comparatively, the overall increase in cooling demand is considerably higher than the 
anticipated decrease in heating demand, and it will outweigh the relative impacts on the net energy demand.

Greece, as a Mediterranean country, has a high vulnerability to the impacts of climate change [32]. At the same time, relevant studies regarding the impacts on buildings' energy use are limited. A study in the early 2000s estimated, for a typical building, that the energy consumption for space heating is expected to decrease by up to $10 \%$ in 2030 , while the cooling consumption is predicted to increase by $28 \%$ [14]. Another study considered only three types of buildings (i.e., residential, office, and education) to quantify that the heating demand for the building sector is projected to decrease by up to $50 \%$ by 2100 , while the cooling demand is expected to increase by as much as $248 \%$, especially in the southern parts of the country [33].

Two approaches are usually applied in order to assess and quantify the potential impacts of climate change on building energy performance. The first general approach is based on statistical analysis of historical data of climatic variables, mainly temperature, and its relationships with energy demand. The major limitation of this method is that long-term socioeconomic and energy system transformation cannot be safely anticipated [34-36]. The second approach employs calculations of buildings' heating/cooling loads and energy use at various levels of detail, with the use of projected future weather data [37,38]. This is handled by general circulation models (GCMs) with a horizontal coarse resolution of 250-600 km over the world [39], or regional climate models (RCMs), with spatial resolution down to $2.5 \mathrm{~km}^{2}$ or even finer [31]. However, the amount of future GHG emissions is a key parameter for predicting how future global warming will contribute to climate change. The projections of GHG emissions vary widely depending on the assumptions regarding population growth, economic development, technological innovation and climate policies. In order to handle these complex parameters for near-term and long-term modelling one can use the representative concentration pathways (RCPs) that have been developed in order to project climate future conditions [40,41]. Accordingly, this work utilizes this approach and considers two scenarios—an adverse and a more optimistic one-for calculating future climate. The most adverse scenario is RCP8.5 in which no climate policies are considered, predicting a continuous rise in GHG concentration until 2100. The more optimistic scenario is RCP4.5 for which the GHG concentrations stabilize after 2100.

This work investigates the impact of climate change on the anticipated energy performance of the existing Hellenic building stock following the second approach, by generating future weather data and using them in a specific calculation tool. The main research question is how would existing buildings (without any renovations) perform under different climate conditions? The aim of this work is to develop a coherent methodology that can be used for an impact assessment of different climate scenarios on the building energy consumption until the end of the century. For demonstration, the work considers different types of Hellenic NR buildings as a case study. The results will provide valuable insight that will be relevant for drafting national building performance regulations and codes and ensure building resilience.

The paper is structured as follows: Section 2 presents the method used, Section 3 presents the case study, and Section 4 the main results of the analysis. Finally, Section 5 summarizes the main findings and outlines the limitations and future work.

\section{Methodology}

The main steps of the method followed in this work for producing future climate data and for estimating buildings' energy performance under climate change, are illustrated in Figure 1 and are elaborated on in the following sections. 


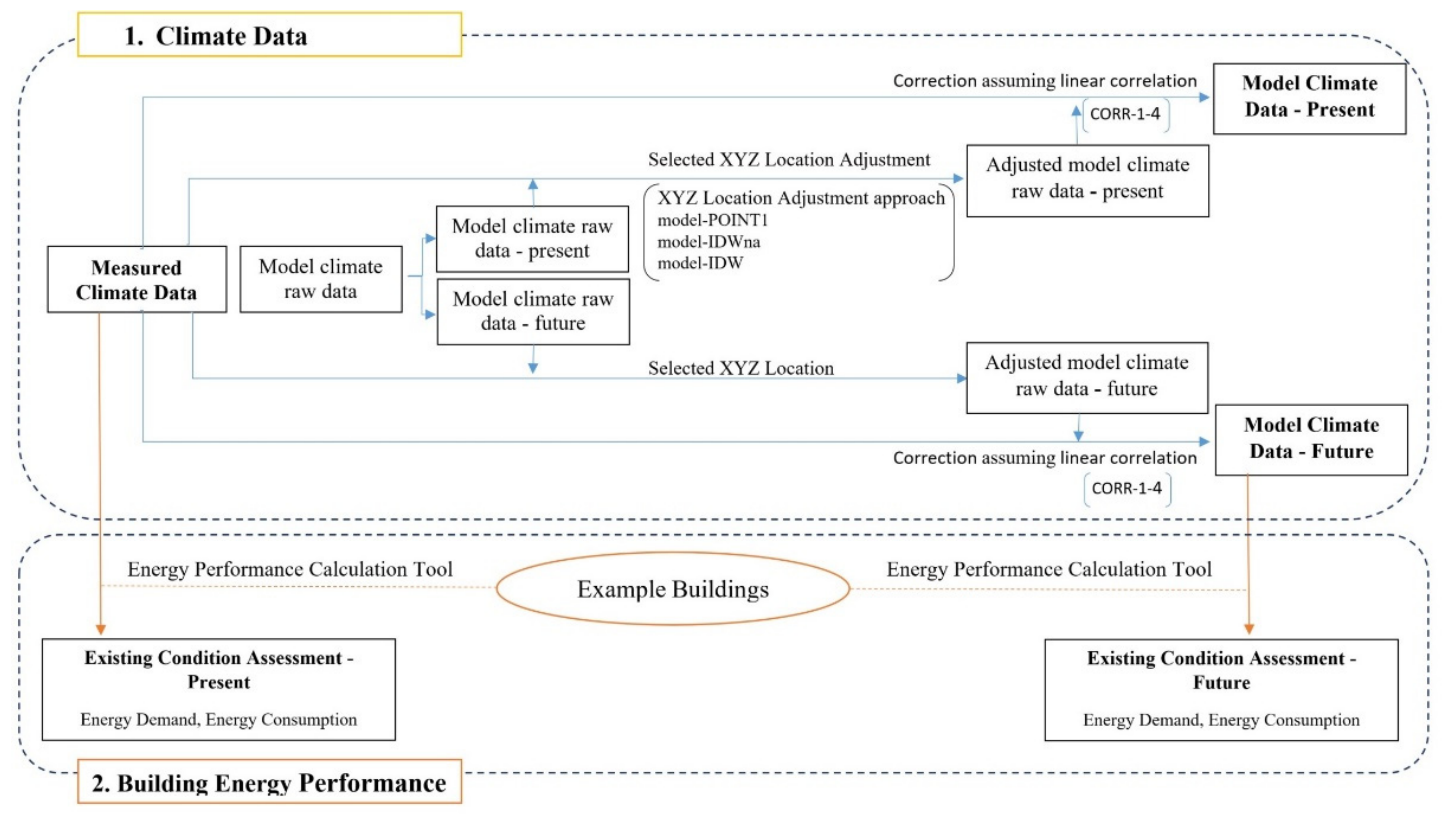

Figure 1. Main steps of the method.

\subsection{Climate Data}

Measured climate data (Figure 1), e.g., air temperature, air humidity, solar irradiation, precipitation, and wind, are collected and recorded with specific instrumentation over long time periods at weather stations around the world and in Greece. Different formats and time steps of the measured data are available and used in the calculations of the energy performance of buildings, depending on the tool.

The model climate raw data (Figure 1) are derived from regional climate models (RCMs), producing time series of data up to 2100 for the various meteorological parameters. The model projections for 2005 correspond to the model climate data-present, while future emission scenarios are implanted in the following simulations. The calculations using the RCMs are performed at grid cells with high $(10-25 \mathrm{~km})$ or very high $(1-10 \mathrm{~km}) \mathrm{spatial}$ resolutions [42]. The implication of this geographic dispersion is that the locations of the calculated model climate raw data will not correspond to the exact locations of the specific weather station sites that provide the corresponding measured climate data.

Accordingly, it is necessary to rectify the data and achieve a better match. The first data correction adapts the model climate raw data to the measured data locations. This mandates a latitude and longitude correction in terms of the location's XY dimensions, as well as an elevation correction ( $Z$ dimension), if necessary. The XYZ location adjustment between model climate raw data-present and measured climate data (Figure 1) can be performed following three different approaches considering the:

- Model climate raw data from the nearest grid point to the specific weather station site compared to the latitude and the longitude of the measured climate data (model-POINT1);

- Weighted average of the model climate raw data for the four nearest grid points using the inverse distance weighting method [43] and taking into account the latitude and the longitude of the climate data locations (model-IDWna);

- Weighted average of the model climate raw data calculated as before, but this time also taking into account the elevation of the climate data locations (model-IDW). The elevation includes the location's altitude and the height of the measurement's point for the climate data. For all measured climate data, the height is taken at $2 \mathrm{~m}$ above ground, while for the model climate data it is taken at $2 \mathrm{~m}$ for the temperature and the humidity, and at $0 \mathrm{~m}$ for the solar irradiation. 
Calculations were performed using all three approaches for the XYZ location adjustment (Figure 1) in order to identify the most appropriate one. The results are evaluated by comparing the adjusted model climate raw data-present with the available measured climate data. The approach with the smallest root mean square error (RMSE) is considered as the most suitable one. As a result, the generated data are referred to as the adjusted model climate raw data-present (Figure 1).

According to the literature [44], climate models overestimate the temperature mainly during the summer for southeastern Europe in regions with wet winters and dry summers. Therefore, a second correction is applied, assuming a linear correlation between the measured climate data and the adjusted model climate raw data-present. Specifically, the linear regression model is applied for each meteorological parameter following four different approaches for:

- All locations of measured climate data (CORR-1), using aggregated data that are averaged over all locations (resulting in one linear regression model);

- Each location of measured climate data (CORR-2), using the data for each location (resulting in one linear regression model per location);

- Each climate zone (CORR-3), using aggregated data that are averaged over all locations in the same climate zone (resulting in one linear regression model per climate zone);

- Each season (CORR-4), using aggregated data that are averaged over all locations for the same season (resulting in one linear regression model per season).

The generated data are referred to as the model climate data-present (Figure 1). Practically there are four data sets of model climate data-present, comprising a zone of data. The results are evaluated by comparing the model climate data-present with the available measured climate data.

The two correction steps, i.e., the XYZ location adjustment and the correction assuming a linear correlation, are then applied to adapt the model climate raw data-future (Figure 1). The resulting data are referred to in the following analysis as the adjusted model climate raw data-future and the model climate data-future, respectively. The model climate data (-present and -future) are used for the calculations of the buildings' energy performance, as discussed in the following section.

\subsection{Building Energy Performance}

A variety of different calculation methods and software can be used for assessing the energy performance of buildings. Depending on the tool, different types of input data are used to describe, among others, the characteristics of the buildings' construction and technical installations and the meteorological parameters (e.g., temperature and solar irradiation) for different calculation time steps that dictate the type of the required climate input data, for example hourly or monthly values.

This phase of the work is used to estimate the energy performance of existing buildings under the prevailing conditions that are reflected by the present and future climate data (Figure 1), which were derived from the previous stage (Section 2.1). This way, it will be possible to predict and assess how the existing building stock will perform under the different evolution scenarios of the prevailing climate conditions. The example buildings (Figure 1) used for the calculations can be real buildings or typical buildings. The idea is to select and study buildings that are representative of the existing building stock in order to perform a more representative analysis.

The results to assess the calculated energy performance may include many different indicators [45]. The most commonly used ones are the energy use intensities [46] that express the buildings' energy demand or energy use per unit floor area $\left(\mathrm{kWh} / \mathrm{m}^{2}\right)$. The calculations may also refer to final and primary energy consumption using the appropriate national conversion factors that, especially for electricity, depend on the energy mix used for power generation. 


\section{Case Study}

A building energy assessment is generally performed using historic or present meteorological data. However, climate change over the building's life span may impact its energy performance. In this case study, the calculations of the buildings' energy performances are performed with the official national calculation engine (TEE KENAK), which is used for issuing the official Energy Performance Certificates (EPC) in Greece. It uses the quasi-steady state monthly method in order to assess the building's energy demand, according to the European standards (e.g., EN 13790) [47].

The end uses considered in the calculations are heating, cooling, domestic hot water, and lighting, while mechanical ventilation is included in heating and cooling. Other office appliances, plug loads, and process loads are neglected. The results that are analyzed in this work are the calculated energy demand per unit floor area $\left(\mathrm{kWh} / \mathrm{m}^{2}\right)$ for space heating and for space cooling and the calculated final energy use per unit floor area $\left(\mathrm{kWh} / \mathrm{m}^{2}\right)$ for both space heating and cooling.

\subsection{Required Climate Data}

The national calculation engine uses monthly values for outdoor air temperature $\left({ }^{\circ} \mathrm{C}\right)$, specific humidity $(\mathrm{g} / \mathrm{kg})$ and total horizontal solar irradiation $\left(\mathrm{MJ} / \mathrm{m}^{2}\right)$. These values are based on official records from the Hellenic National Meteorological Service available for 62 Hellenic cities. They were derived from a 30 year series of meteorological measured data (from 1970 up to 2000), with the use of appropriate empirical or mathematical approaches. These data are defined in a national technical guideline [47], constituting the measured climate data (Figure 1) in our case study and were used in the calculations of the buildings energy performance in the present conditions.

Furthermore, 3 hourly data were used from the regional climate model RCA4 of the Swedish Meteorological and Hydrological Institute [48], which is dynamically downscaled from the Global Climate Model MPI-ESM-LR of the Max Planck Institute for Meteorology [49]. The simulations were carried out in the framework of the EURO-CORDEX with a horizontal resolution of $\sim 12.5 \mathrm{~km}[50]$.

The model climate raw data (Figure 1) that was used in this example to provide the necessary inputs for the calculation engine, included values for outdoor air temperature $\left({ }^{\circ} \mathrm{C}\right)$, relative humidity $(\%)$, and solar horizontal irradiation $\left(\mathrm{W} / \mathrm{m}^{2}\right)$ for the 62 Hellenic cities. The data were derived for consecutive years from three time periods that correspond to the present (1981-2000), the near future (2041-2060) and the distant future (2081-2100). The model climate raw data were adapted in order to comply with the input requirements of the official national calculation engine used in this work, following the discussion in Section 2.1. Accordingly, monthly averages of the outdoor air temperature $\left({ }^{\circ} \mathrm{C}\right)$, specific humidity $(\mathrm{g} / \mathrm{kg})$, and total horizontal solar irradiation $\left(\mathrm{MJ} / \mathrm{m}^{2}\right)$ were calculated for each year of the time series.

In this work, two RCP scenarios (Section 1) were selected. The first one is the baseline scenario for continuing business as usual, with increasing GHG levels and no mitigation policies (RCP8.5). The second is an intermediate stabilization scenario assuming the imposition of conservative emissions mitigation policies, considered as the more likely to occur (RCP4.5). The model climate raw data (Figure 1) for a specific year was estimated as the average over a ten year period before and after the individual year. The base year of the model is centered at 1990, which refers to the present time period and which was computed by averaging the monthly values over the time period 1981-2000. Similarly, the near and distant future time periods corresponded to the year 2050 and 2090, averaging data between 2041-2060 and 2081-2100, respectively. For the present time period, the data between the two RCP scenarios were identical. As a result, five sets of model climate raw data were defined, i.e., one for the present and two for each future time period.

The model climate data-present were used only as a reference period in order to correct the modelled against the measured data, while in the calculations the measured climate data were used. The two correction steps (XYZ location adjustment and the 
correction assuming a linear correlation that was elaborated in Section 2.1) were applied to the model climate raw data-future that correspond to the 62 Hellenic cities considered in this study. As a result, a total of seventeen sets of model climate data were used in the calculations. One dataset corresponds to the present and sixteen datasets to the future projections, including eight sets for the near and eight sets for the distant future.

\subsection{Hellenic Example Buildings}

The example buildings used for the calculations in this case study were real buildings located in different Hellenic cities. In line with the national technical guidelines, Greece is divided into four climate zones, depending on annual heating degree days (HDD); Zone A in the south includes most of the islands and is characterized by mild climate conditions, with an average of 859 HDD; Zone B includes the greater metropolitan area of Athens, averaging 1164 HDD. The regions with the most adverse winter conditions include Zone C in the central and northern parts of the country, with $1825 \mathrm{HDD}$ and Zone D in the north with the coldest conditions, with 2260 HDD.

Specifically, this case study exploited available information from energy audits of Hellenic NR whole buildings, which were performed for issuing an EPC over a six year period (up to December 2016). The relevant information included general data about the building (e.g., location, construction date orientation), construction characteristics of the envelope (e.g., area, U-value) and technical information about the electromechanical installations (e.g., system types, fuels, efficiency coefficients). The available data were used as inputs to the national calculation engine, along with the Measured and Model Climate Data.

Usually, the available information from building energy audits is not easily accessible. The energy audit files are in the form of extensible markup language (XML) files, which are basically plain text files using custom tags to store data. These files are directly readable from the calculation engine used for issuing the EPCs. The input data from the XML files of the energy audits are used as case studies, resembling the distribution of the national building stock.

In Greece, the Hellenic Ministry of Environment and Energy performs the first level data quality controls [51]. During this work an additional two level cleansing procedure was also applied to the available data in order to identify and exclude incomplete or problematic data and probable outliers, thus ensuring the reliability of the results. By the end of 2016, a total of about 24,000 energy audits of NR whole buildings have been officially submitted to the national electronic repository (buildingcert). Applying the additional screening process, the resulting high-quality database included 2445 energy audits of NR whole buildings (used as example buildings in the following analysis).

\section{Results and Discussion}

This work investigated the impact of climate change on the calculated energy use of real NR buildings until the end of the century. The first step was the generation of climate data in 62 Hellenic cities for two average climatic projections (RCP8.5 and RCP4.5) in the near (2050) and the distant future (2090). Specifically, the results included monthly values for the outdoor air temperature $\left({ }^{\circ} \mathrm{C}\right)$, specific humidity $(\mathrm{g} / \mathrm{kg})$ and total horizontal solar irradiation $\left(\mathrm{MJ} / \mathrm{m}^{2}\right)$. These data were then used in the calculations for estimating the energy performance of real NR buildings in their existing condition. The buildings' energy demand and energy use for heating and cooling were assessed in an attempt to analyze the response of existing buildings to climate change.

\subsection{Future Climate Data}

The first step for the generation of the future weather data at the 62 Hellenic cities that were used for the calculations was the $X \curlyvee Z$ location adjustment between the monthly model climate data-present and the measured climate data. This was performed by applying the three different approaches, i.e., model-POINT1, model-IDWna, and model-IDW, elaborated 
on in Section 2.1. In order to define the best approach, the average annual values for the three meteorological parameters were estimated and the RMSE of the differences between the model climate data-present and the measured climate data were calculated and summarized in Table 1. The minimum RMSE for all three parameters was obtained with the model-IDW approach, which presented the best fit. As a result, the specific approach was also applied to the model climate raw data for the two future time periods (i.e., the near and the distant future) and both RCP scenarios (i.e., RCP4.5 and RCP8.5).

Table 1. Comparison of the root mean square errors between the model and measured climate data for the present period (1981-2000).

\begin{tabular}{cccc}
\hline XYZ Location Adjustment & Air Temperature $\left({ }^{\circ} \mathbf{C}\right)$ & Specific Humidity $(\mathbf{g} / \mathbf{k g})$ & \left.${\text { Horizontal Irradiation }\left(\mathbf{M J} / \mathbf{m}^{2}\right)}\right)^{2}$ \\
model-POINT1 & 1.9 & 1.4 & 102.0 \\
model-IDWna & 2.0 & 1.4 & 99.0 \\
model-IDW & 1.8 & 1.3 & 101.4 \\
\hline
\end{tabular}

The second step was the correction assuming a linear correlation of the adjusted model climate raw data (Figure 1). This was done by applying the four linear regression models (elaborated on in Section 2.1 and identified as CORR-1 up to CORR-4), to the present, near (2050) and distant (2090) future for both RCP4.5 and RCP8.5. The resulting average annual values for the three meteorological parameters are presented in Table 2.

Table 2. Annual average Measured and Model Climate Data.

\begin{tabular}{|c|c|c|c|c|c|c|}
\hline \multirow[t]{2}{*}{ Time Periods } & \multirow{2}{*}{$\begin{array}{c}\text { Representative } \\
\text { Concentration } \\
\text { Pathways }\end{array}$} & \multirow{2}{*}{$\begin{array}{c}\text { Measured } \\
\text { Climate Data }\end{array}$} & \multicolumn{4}{|c|}{$\begin{array}{c}\text { Model Climate Data } \\
\text { Linear Regression Models }\end{array}$} \\
\hline & & & CORR-1 & CORR-2 & CORR-3 & CORR-4 \\
\hline \multicolumn{7}{|c|}{ Air Temperature ${ }^{1}\left({ }^{\circ} \mathrm{C}\right)$} \\
\hline Present & & 16.8 & 16.8 & 16.8 & 16.8 & 16.8 \\
\hline \multirow{2}{*}{ Near Future-2050 } & RCP4.5 & & 18.3 & 18.4 & 18.3 & 18.1 \\
\hline & RCP8.5 & & 18.8 & 18.8 & 18.8 & 18.5 \\
\hline Distant & RCP4.5 & & 18.5 & 18.6 & 18.5 & 18.3 \\
\hline Future-2090 & RCP8.5 & & 21.1 & 21.2 & 21.1 & 20.5 \\
\hline \multicolumn{7}{|c|}{ Specific Humidity $^{2}(\mathrm{~g} / \mathrm{kg})$} \\
\hline Present & & 8.1 & 8.1 & 8.1 & 8.1 & 8.1 \\
\hline \multirow{2}{*}{ Near Future-2050 } & $\mathrm{RCP} 4.5$ & & 8.7 & 8.9 & 8.8 & 8.6 \\
\hline & RCP8.5 & & 9.0 & 9.3 & 9.1 & 8.8 \\
\hline Distant & RCP4.5 & & 8.9 & 9.1 & 8.9 & 8.7 \\
\hline Future-2090 & RCP8.5 & & 9.9 & 10.4 & 10.1 & 9.5 \\
\hline \multicolumn{7}{|c|}{ Solar Irradiation ${ }^{3}\left(\mathrm{MJ} / \mathrm{m}^{2}\right)$} \\
\hline Present & & 484 & 483 & 483 & 483 & 481 \\
\hline \multirow{2}{*}{ Near Future-2050 } & RCP4.5 & & 484 & 484 & 484 & 481 \\
\hline & RCP8.5 & & 484 & 484 & 484 & 482 \\
\hline Distant & RCP4.5 & & 483 & 483 & 483 & 480 \\
\hline Future-2090 & RCP8.5 & & 485 & 485 & 485 & 483 \\
\hline
\end{tabular}

${ }^{1}$ Average annual air temperature for all Hellenic cities $\left({ }^{\circ} \mathrm{C}\right) .{ }^{2}$ Average annual specific humidity for all Hellenic cities $(\mathrm{g} / \mathrm{kg}) .{ }^{3}$ Average annual horizontal irradiation for all Hellenic cities $\left(\mathrm{MJ} / \mathrm{m}^{2}\right)$.

The future annual temperature and specific humidity will increase, which is consistent with theoretical expectations for global warming $[13,52]$. On the other hand, the average monthly solar irradiation will not be significantly affected, which is in line with the findings in [13]. In general, only a limited number of studies address future projections of solar radiation [53]. Focusing on Europe, projections about the magnitude and even the sign of radiation changes are not very clear [54,55]. As a general rule, solar irradiance is mostly affected by cloud cover, which presents a behavioral variation in global and regional climate models [56]. Thus, the projected solar irradiation data presented different trends 
for different cities, which were neutralized when averaged across Greece. Consequently, the following analysis will focus on air temperature and specific humidity.

The results for the near and distant future time periods are very close among the four different regression models (Table 3). On average, CORR-4 results in the lowest values, while CORR-2 in the highest. Solar irradiation presents the lowest dispersion around the mean in all cases with a coefficient of variation $(\mathrm{CV})$ of $0.3-0.4 \%$. Air temperature values also have a low variance (CV of $1-2 \%$ ), while specific humidity has the highest dispersion for the distant future time period ( $\mathrm{CV}$ of $4-6 \%$ ).

Table 3. Statistical analysis of Model Climate Data for near- and distant- future.

\begin{tabular}{ccccc}
\hline & \multicolumn{2}{c}{ Near Future-2050 } & \multicolumn{2}{c}{ Distant Future-2090 } \\
& RCP4.5 & RCP8.5 & RCP4.5 & RCP8.5 \\
\hline Range & Air Temperature $\left({ }^{\circ} \mathrm{C}\right)$ & & \\
Variance & 0.3 & 0.3 & 0.3 & 0.7 \\
Standard deviation & 0.0 & 0.0 & 0.0 & 0.1 \\
Average & 0.1 & 0.2 & 0.1 & 0.3 \\
Coefficient of variation & 18.3 & 18.7 & 18.5 & 21.0 \\
& 0.7 & 0.8 & 0.8 & 1.6 \\
Range & Specific Humidity $(\mathrm{g} / \mathrm{kg})$ & & 0.9 \\
Variance & 0.3 & 0.5 & 0.3 & 0.1 \\
Standard deviation & 0.0 & 0.0 & 0.0 & 0.4 \\
Average & 0.1 & 0.2 & 0.1 & 6.6 \\
Coefficient of variation & 8.7 & 6.0 & 8.9 & 5.6 \\
Range & 1.3 & 3.6 & 1.6 & 2.3 \\
Variance & Solar Horizontal Irradiation $\left(\mathrm{MJ} / \mathrm{m}^{2}\right)$ & & 1.3 \\
Average & 2.7 & 2.4 & 2.6 & 1.1 \\
Standard deviation & 1.8 & 1.4 & 1.7 & 323.4 \\
Coefficient of variation & 1.3 & 1.2 & 1.3 & 0.3 \\
\hline
\end{tabular}

The model climate data resulting from the two scenarios are in closer agreement for the near future time period, while they exhibit high deviations for the distant future. This can be attributed to the fact that the main driving force for the model climate data is the GHG concentrations, which present lower discrepancies between the RCPs in 2050 and higher discrepancies in 2090 [57]. RCP8.5 gives a much more rapid warming and more pronounced changes in climate data indicators (e.g., temperature) until the end of the century. As a result, air temperature and specific humidity present higher differences between the near and the distant future under RCP8.5 corresponding to 8-13\%, compared to $\mathrm{RCP} 4.5$ that reach $1-2 \%$.

In the baseline scenario (RCP8.5), the annual air temperature increases from the present value of $16.8^{\circ} \mathrm{C}$ by $10-12 \%$ which corresponds to $1.5-1.8 \mathrm{~K}$ for 2050 , and by $22-26 \%$ which corresponds to $3.7-4.5 \mathrm{~K}$ for 2090, depending on the correction procedure (Figure 2a). In the intermediate scenario (RCP4.5), the increase ranges between $8-10 \%(1.3-1.6 \mathrm{~K})$ for 2050 and between $9-11 \%$ (1.5-1.8 K) for 2090. Relatively similar deviations are also observed for the annual specific humidity, which increases by $8-14 \%(0.6-1.1 \mathrm{~g} / \mathrm{kg})$ for 2050 and by $17-28 \%(1.4-2.2 \mathrm{~g} / \mathrm{kg})$ for 2090, according to RCP8.5 (Figure $2 \mathrm{~b}$ ). The increase is smaller in $\mathrm{RCP} 4.5$, ranging between 6-9\% (0.5-0.7 g/ $\mathrm{kg})$ for 2050 and between $7-12 \%(0.6-0.9 \mathrm{~g} / \mathrm{kg})$ for 2090 . 


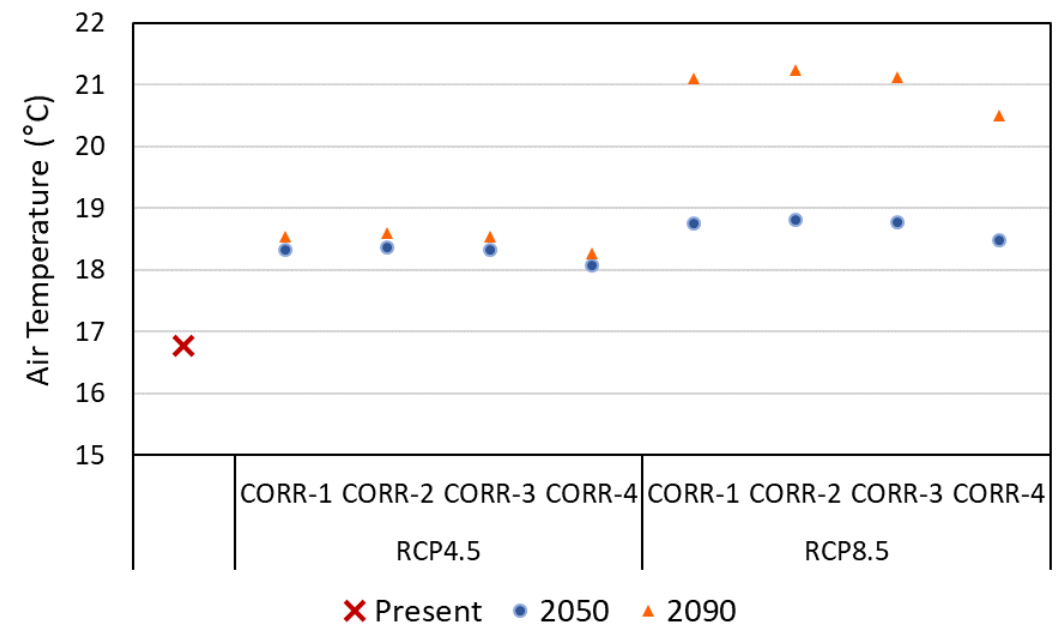

(a)

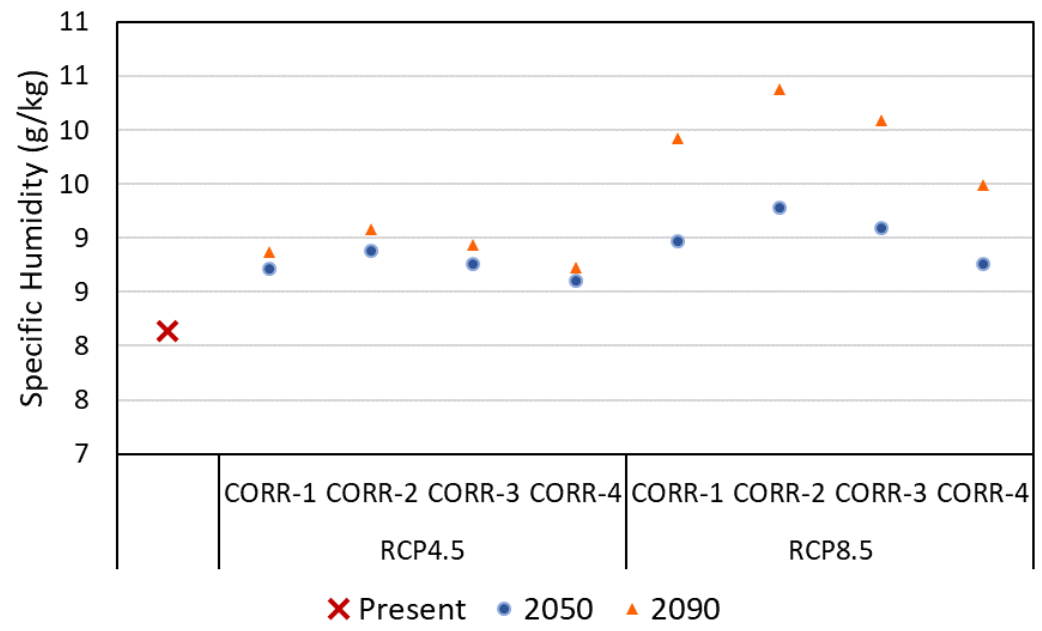

(b)

Figure 2. Annual average air temperature (a) and specific humidity (b) for all locations. The "Present" corresponds to measured climate data, while "2050" and "2090" correspond to model climate data for the near and distant future.

The temperature increase is higher in the colder parts of the country. Specifically, with the RCP8.5, the annual air temperature increases by $10 \%$ for climate zone A and by $17 \%$ for climate zone D for 2050, while for 2090, the corresponding increase ranges from $21 \%$ to $37 \%$ (Figure 3). Using the RCP4.5, the increase ranges between 8-14\% for 2050 and between $9-16 \%$ for 2090 . For the specific humidity there is not a clear trend in the deviations among the various climate zones (Figure 3).

The lowest annual national average temperature was projected to increase from $11.7^{\circ} \mathrm{C}$ (present) to $13.2^{\circ} \mathrm{C}$ under RCP4.5 and $13.6{ }^{\circ} \mathrm{C}$ under RCP8.5 in the near future (an increase by $13-16 \%$ ), and to $13.4^{\circ} \mathrm{C}$ and $16.1^{\circ} \mathrm{C}$, respectively, in the distant future (an increase by $14-37 \%)$. On the other hand, the highest annual national average temperature of $19.7^{\circ} \mathrm{C}$ (present) was projected to increase to $21.0^{\circ} \mathrm{C}$ under RCP4.5 and $21.3^{\circ} \mathrm{C}$ under RCP8.5 in the near future (an increase by $6-8 \%$ ), and to $21.2^{\circ} \mathrm{C}$ and $23.4{ }^{\circ} \mathrm{C}$, respectively, in the distant future (an increase by 7-19\%). The cities with the highest percentages of temperature increase (both in near and distant future) were located in the colder zones of the country (i.e., Florina, Alexandroupoli, Kozani, and Trikala Imathias, identified in Figure 3). 


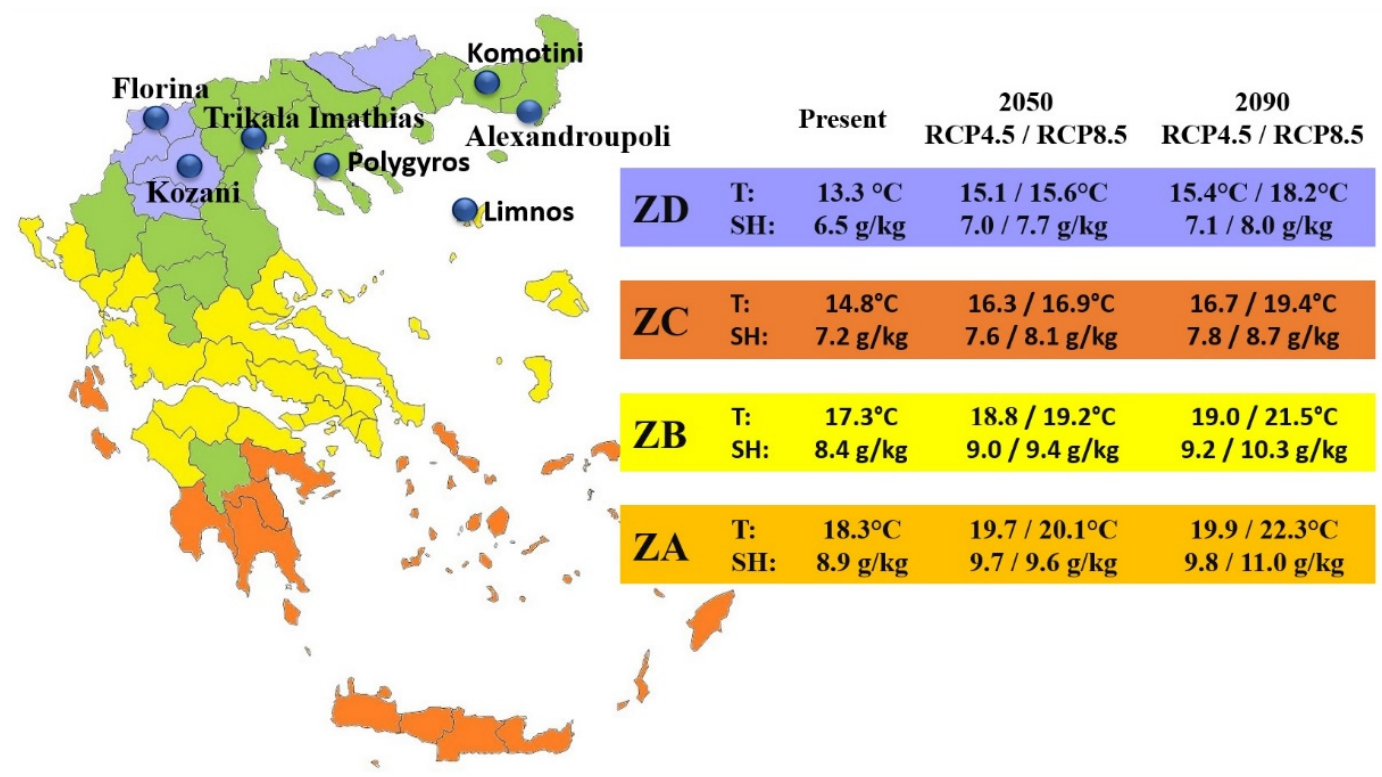

Figure 3. Average annual air temperature $(\mathrm{T})$ and specific humidity $(\mathrm{SH})$ per climate zone (ZA-ZD), for the present, the near future (2050), and the distant future (2090). The identified cities correspond to the locations with the highest percentage increase of temperature and cooling energy use to help visualize the conclusions (in Section 5).

\subsection{Building Energy Performance Indicators}

The energy performance of the NR buildings was assessed for their existing condition using the measured climate data, as well as the model climate data for the near and distant future time periods for both RCP scenarios. The building characteristics from 2445 energy audits located in 62 cities around the country were used as input in the calculation engine. Considering all possible combinations, the total number of calculations reached 41,565 cases. Since climate change affects mainly space heating and cooling, the results for the energy consumption of domestic hot water and lighting are not presented in detail in the following discussion.

A first attempt for defining the impact of the two meteorological parameters on energy demand and energy use was made by analyzing the $R$ squared $\left(R^{2}\right)$, presented in Figure 4 . The air temperature had the most significant impact on heating and cooling demand as well as on heating energy use, while specific humidity was the most important factor for cooling energy use.

The heating demand and energy use are expected to decrease in the future since the air temperature increases due to climate change, while cooling demand and energy use are expected to increase. Specifically, compared to the present, the average heating demand in the case of scenario RCP4.5 decreased between $23-28 \%$ for both near and distant future time periods (depending on the assumed linear correlation). In RCP8.5, the decrease in the near future was comparable to the results in RCP4.5 (ranging from $26 \%$ to $31 \%$ ). However, for the distant future, there was a more significant decrease of $54-60 \%$. Similarly, the average heating energy use decreased by $20-25 \%$ in RCP4.5 (for both the near and distant future), while in RCP8.5 the decrease ranged between $23-27 \%$ in the near future and between $48-54 \%$ in the distant future. The heating demand ratio for the near future regarding the present for RCP4.5 is 0.75 , which is comparable to 0.93 for Greece [27]. This is a satisfactory agreement taking into account that in the latter study, heating demand is estimated using a different approach and that it also included residential buildings and not just NR buildings, as in this work.

On the other hand, the increase in average cooling demand in the case of scenario RCP4.5 ranged between 16-32\% and 21-39\% for the near and distant future, respectively, while for scenario RCP8.5 the increase ranged between $20-37 \%$ and $51-82 \%$. Similarly, in the case of scenario RCP4.5, the cooling energy use increased by $15-29 \%$ and by $19-36 \%$ for 
the near and the distant future, while in RCP8.5, the corresponding decrease ranged by $18-33 \%$ and $47-75 \%$. The cooling demand ratio for the near future regarding the present for RCP4.5 is 1.26, which is in very close agreement with the value of 1.25 that was estimated for the Hellenic building sector in [27].
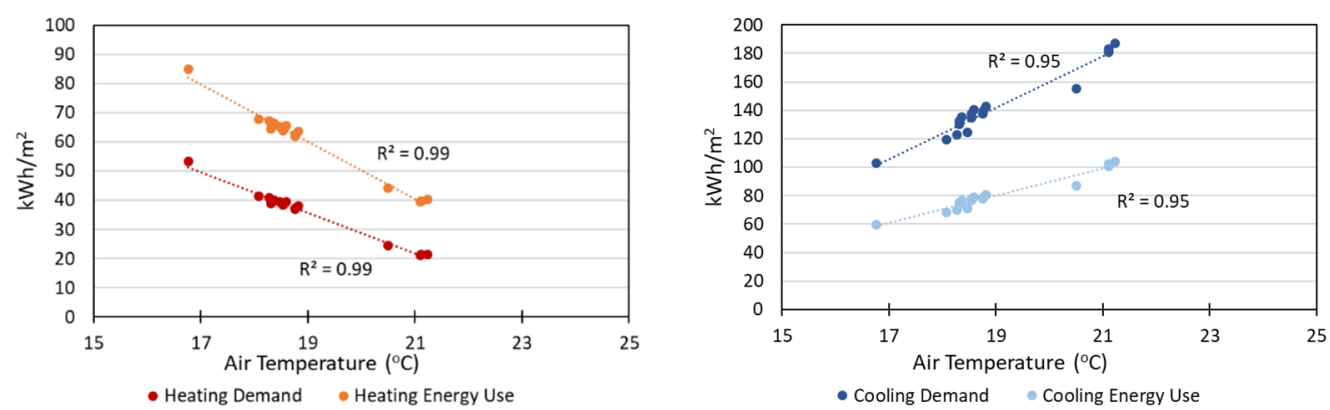

(a)
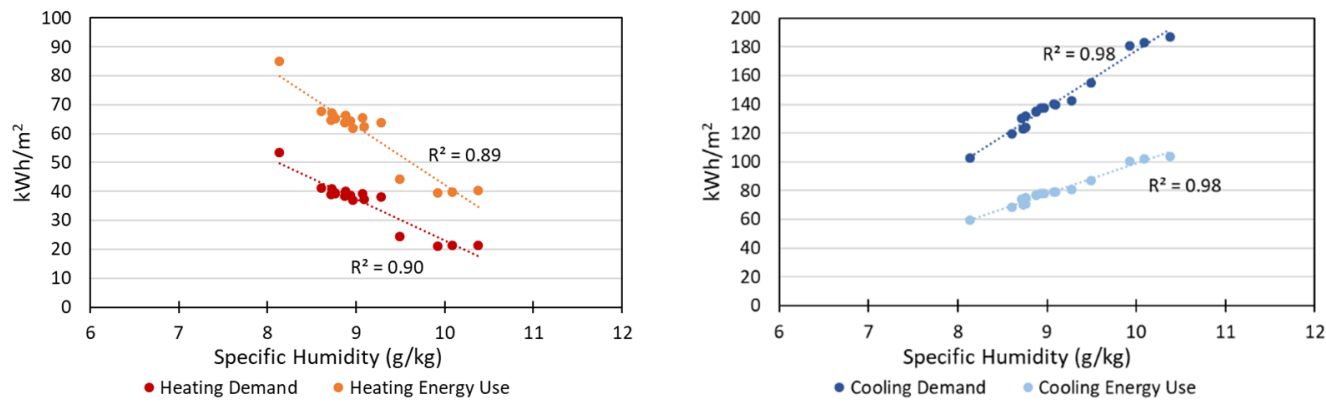

(b)

Figure 4. Impact of (a) air temperature and (b) specific humidity on heating (left column) and cooling (right column) energy demand and energy use.

On a national basis, the increase in average cooling demand was higher than the decrease in average heating demand. As a result, the average net heating and cooling demand increased for the near and distant future time period. In case of RCP8.5, the average net heating and cooling demand increased by $5-16 \%$ for the near future and between $15-34 \%$ for the distant future (depending on the assumed linear correlation). In RCP4.5, the increase for the near and distant future was comparable to the results in RCP4.5 near future, ranging by $3-12 \%$ and $5-15 \%$, respectively. On the other hand, average net heating and cooling energy use decreased by $0-6 \%$ in RCP4.5 (for both the near and distant future), while in RCP8.5 the decrease ranged by $0-9 \%$.

The demand and the energy use for heating, cooling, and net (heating and cooling) in the different climate zones (ZA to ZD) as well as on a national basis $(\mathrm{N})$ are summarized in Table 4 . The decrease rate in heating demand and energy use progressively increases from colder to warmer climate zones. Specifically, for the scenario RCP8.5, the decrease in the heating demand (or heating energy use) ranged from $23 \%$ (or 20\%) in climate zone D up to $36 \%$ (or 31\%) in climate zone A in 2050. The corresponding results in 2090 ranged from $48 \%$ (or $46 \%$ ) to $68 \%$ (or $59 \%$ ). Considering RCP4.5, the decrease in heating demand (or heating energy use) for the near and distant future was similar, ranging from $21 \%$ (or $19 \%$ ) to $32 \%$ (or $28 \%$ ) in 2050 , and from $22 \%$ (or $20 \%$ ) to $33 \%$ (or $29 \%$ ) in 2090 . On the other hand, the increase rate in cooling demand and energy use increased from warmer to colder climate zones. In RCP8.5, the cooling demand (or cooling energy use) increased from $25 \%$ (or 23\%) in climate zone A to $69 \%$ (or 57\%) in climate zone D in 2050. The results in 2090 ranged from $64 \%$ (or $58 \%$ ) to $138 \%$ (or $115 \%$ ). In RCP4.5, the increase rate ranged from $18 \%$ (or $17 \%$ ) to $62 \%$ (or $51 \%$ ) in 2050 , and from $23 \%$ (or $21 \%$ ) to $70 \%$ (or $58 \%$ ) in 2090 . These results are in line with the corresponding findings of a previous study on the projections 
of energy demand of the building sector in Greece [33], taking into account the different climate scenarios considered in the two studies.

Table 4. Annual average demand and energy use for heating, cooling and total heating and cooling in the four climate zones (ZA to ZD) and on a national basis $(\mathrm{N})$ from the measured and the model climate data.

\begin{tabular}{|c|c|c|c|c|c|}
\hline & \multirow{3}{*}{$\begin{array}{c}\text { Measured Climate Data } \\
\text { Present } \\
\text { Avg }\end{array}$} & \multicolumn{4}{|c|}{ Model Climate Data } \\
\hline & & \multicolumn{2}{|c|}{ Near Future-2050 } & \multicolumn{2}{|c|}{ Distant Future-2090 } \\
\hline & & $\begin{array}{c}\text { RCP4.5 } \\
\text { Avg [Min-Max] }\end{array}$ & $\begin{array}{c}\text { RCP8.5 } \\
\text { Avg [Min-Max] }\end{array}$ & $\begin{array}{c}\text { RCP4.5 } \\
\text { Avg [Min-Max] }\end{array}$ & $\begin{array}{c}\text { RCP8.5 } \\
\text { Avg [Min-Max] }\end{array}$ \\
\hline \multicolumn{6}{|c|}{ Heating Demand $\left(\mathrm{kWh} / \mathrm{m}^{2}\right)$} \\
\hline $\mathrm{ZA}$ & 31.3 & $21.2[20.2-23.1]$ & $20.1[19.2-22.2]$ & $20.9[19.9-22.9]$ & $10.1[9.2-12.6]$ \\
\hline $\mathrm{ZB}$ & 50.9 & $39.1[37.6-41.2]$ & $37.3[35.8-39.5]$ & $38.7[37.1-40.8]$ & $21.2[19.6-24.1]$ \\
\hline $\mathrm{ZC}$ & 93.8 & $70.4[67.7-75.6]$ & $66.7[64.0-71.5]$ & $69.1[66.3-74.1]$ & $42.2[40.2-44.8]$ \\
\hline ZD & 152.3 & $120.5[116.9-124.3]$ & $116.5[113.0-120.3]$ & 118.9 [115.5-122.7] & $78.5[76.5-80.5]$ \\
\hline $\mathrm{N}$ & 53.4 & $39.8[38.9-41.3]$ & $38.0[37.0-39.5]$ & $39.3[38.3-40.8]$ & $22.1[21.1-24.5]$ \\
\hline \multicolumn{6}{|c|}{ Heating Energy Use $\left(\mathrm{kWh} / \mathrm{m}^{2}\right)$} \\
\hline $\mathrm{ZA}$ & 48.9 & $35.0[33.6-37.6]$ & $33.6[32.2-36.3]$ & $34.6[33.2-37.2]$ & $20.3[19.1-23.6]$ \\
\hline $\mathrm{ZB}$ & 76.4 & $61.2[58.9-64.0]$ & $58.9[56.6-61.8]$ & $60.7[58.4-63.6]$ & $37.6[35.3-41.6]$ \\
\hline $\mathrm{ZC}$ & 154.9 & $123.4[116.6-130.4]$ & $127.8[119.7-135.4]$ & $126.5[118.7-133.8]$ & 165.9 [146.0-177.5] \\
\hline ZD & 310.7 & $250.3[243.3-258.0]$ & $242.2[235.4-249.7]$ & $247.2[240.5-254.7]$ & $168.3[164.3-172.5]$ \\
\hline $\mathrm{N}$ & 85.1 & $66.0[64.6-67.8]$ & $63.3[62.0-65.3]$ & $65.2[63.8-67.1]$ & $41.0[39.6-44.1]$ \\
\hline \multicolumn{6}{|c|}{ Cooling Demand $\left(\mathrm{kWh} / \mathrm{m}^{2}\right)$} \\
\hline $\mathrm{ZA}$ & 101.8 & 120.5 [111.2-130.9] & $127.6[116.1-139.4]$ & $125.4[114.7-136.7]$ & $167.1[146.0-184.0]$ \\
\hline $\mathrm{ZB}$ & 114.8 & $144.8[132.9-150.2]$ & $152.5[138.4-159.0]$ & $149.7[136.4-155.9]$ & $196.1[172.7-205.9]$ \\
\hline $\mathrm{ZC}$ & 86.2 & $123.4[116.6-130.4]$ & $127.8[119.7-135.4]$ & $126.5[118.7-133.8]$ & 165.9 [146.0-177.5] \\
\hline ZD & 68.9 & $111.8[109.9-114.0]$ & 116.8 [113.1-119.6] & $117.2[114.0-120.2]$ & 164.5 [147.4-171.9] \\
\hline $\mathrm{N}$ & 105.2 & $132.5[122.4-138.5]$ & $139.5[127.3-146.3]$ & $137.1[125.7-43.7]$ & 181.0 [159.0-191.9] \\
\hline \multicolumn{6}{|c|}{ Cooling Energy Use $\left(\mathrm{kWh} / \mathrm{m}^{2}\right)$} \\
\hline $\mathrm{ZA}$ & 57.5 & $67.1[62.3-72.5]$ & $70.7[64.8-76.9]$ & $69.6[64.1-75.5]$ & $91.1[80.2-99.8]$ \\
\hline $\mathrm{ZB}$ & 67.0 & $83.2[76.8-86.1]$ & $87.3[79.8-90.8]$ & $85.8[78.6-89.2]$ & 110.6 [98.1-115.9] \\
\hline $\mathrm{ZC}$ & 50.8 & $70.5[66.8-74.2]$ & $72.8[68.5-76.8]$ & $72.1[67.9-76.0]$ & $93.1[82.4-99.2]$ \\
\hline ZD & 44.6 & $67.5[66.4-68.8]$ & $70.2[68.1-71.9]$ & $70.5[68.6-72.1]$ & $95.8[86.5-99.9]$ \\
\hline $\mathrm{N}$ & 60.9 & $75.4[70.0-78.5]$ & $79.1[72.6-82.6]$ & $77.8[71.8-81.2]$ & $101.0[89.3-106.6]$ \\
\hline \multicolumn{6}{|c|}{ Heating \& Cooling Demand $\left(\mathrm{kWh} / \mathrm{m}^{2}\right)$} \\
\hline ZA & 133.2 & $141.7[134.3-152.0]$ & $147.7[138.2-59.3]$ & $146.2[137.6-157.4]$ & $177.2[158.6-193.1]$ \\
\hline $\mathrm{ZB}$ & 165.7 & $183.9[174.1-189.4]$ & 189.9 [177.9-196.4] & $188.4[177.2-194.7]$ & $217.3[196.9-226.6]$ \\
\hline $\mathrm{ZC}$ & 168.0 & $176.6[170.0-182.7]$ & $176.6[169.0-183.1]$ & $177.9[170.5-184.3]$ & $184.9[168.8-193.3]$ \\
\hline ZD & 212.9 & $218.7[213.5-221.8]$ & $219.1[212.4-222.5]$ & $221.9[215.7-225.1]$ & $223.1[207.5-229.2]$ \\
\hline $\mathrm{N}$ & 156.0 & $169.1[160.7-175.0]$ & $174.0[163.7-180.7]$ & $173.1[163.5-179.5]$ & $198.6[179.6-208.6]$ \\
\hline \multicolumn{6}{|c|}{ Heating \& Cooling Energy Use $\left(\mathrm{kWh} / \mathrm{m}^{2}\right)$} \\
\hline $\mathrm{ZA}$ & 106.4 & $102.1[99.3-107.8]$ & $104.4[101.1-110.6]$ & $104.2[101.3-110.2]$ & 111.4 [103.7-119.1] \\
\hline $\mathrm{ZB}$ & 143.5 & $144.4[140.8-147.6]$ & $146.2[141.6-150.0]$ & $146.5[142.2-150.1]$ & $148.3[139.7-153.1]$ \\
\hline $\mathrm{ZC}$ & 198.5 & $179.4[174.3-188.3]$ & 175.7 [170.9-184.5] & 178.8 [173.9-187.6] & $155.9[148.2-163.4]$ \\
\hline ZD & 349.9 & 309.6 [301.6-316.7] & 303.9 [295.2-311.1] & 309.1 [300.8-316.1] & $252.5[243.0-258.4]$ \\
\hline $\mathrm{N}$ & 144.6 & 139.5 [136.2-143.0] & 140.5 [136.1-144.3] & 141.1 [137.1-144.8] & 139.4 [131.3-144.3] \\
\hline
\end{tabular}

The two colder climate zones in northern Greece (i.e., ZC and ZD) are projected to experience higher average cooling energy use for NR buildings compared to the warmer climate zone (ZA). Climate zone B (including the metropolitan area of Athens) has the highest average cooling energy use for NR buildings in the present and is projected to have the highest values both in the near future (increased by $24-30 \%$ ) and in the distant future $(28-65 \%)$. The cities with the higher percentages of cooling energy use increase (both in near and distant future) are located in the northern parts of the country (i.e., Polygyros, Limnos, Komotini, and Florina, identified in Figure 3).

The energy use for heating, cooling, and the net (heating and cooling) for the existing Hellenic NR building stock are estimated for the present at 1.02 Mtoe, 0.73 Mtoe and 1.74 Mtoe, respectively. For the near future, the corresponding projected values are 0.76-0.79 Mtoe (using the RCP8.5-RCP4.5) for heating, 0.95-0.91 Mtoe for cooling, and 
1.69-1.68 Mtoe for the total energy use. Finally, in 2090, the corresponding values are 0.49-0.78 Mtoe, 1.22-0.94 Mtoe, and 1.68-1.70 Mtoe.

\section{Conclusions}

This work investigated the potential impacts of climate change on the energy performance of existing buildings until the end of the century. The approach involved two main steps. The first one addressed the generation of future weather data for the near future (2050) and the distant future (2090) following two climate scenarios. The baseline scenario (RCP8.5), which was used to project the consequences of continuing current practices, represented the scheme with the highest GHG emissions. The intermediate stabilization scenario (RCP4.5), which is considered as the most likely to occur, assumed the imposition of conservative emissions mitigation policies. The model climate raw data were first adjusted for the measured data location, and then they were corrected using four different linear regression models. For demonstration, a total of sixteen sets of model climate data were generated for 62 Hellenic cities spread around Greece.

According to the application results, the annual average air temperature for Greece in 2050 was projected to increase by $1.5 \mathrm{~K}$ for the RCP4.5 scenario and by $1.9 \mathrm{~K}$ for the RCP8.5 scenario. In 2090, the increase was estimated to reach $1.7 \mathrm{~K}$ and $4.2 \mathrm{~K}$, respectively. This is in line with the projections that have been reported in the literature [58] for increased European land temperatures by 1.4 to $4.2 \mathrm{~K}$ in different regions under RCP 4.5 and by 2.7 to 6.2 K under RCP8.5 (by 2071-2100, compared to 1971-2000). Specific humidity presented similar behavior, increasing by $0.6 \mathrm{~g} / \mathrm{kg}$ for RCP4.5 and by $0.9 \mathrm{~g} / \mathrm{kg}$ for RCP8.5 in 2050, and by $0.8 \mathrm{~g} / \mathrm{kg}$ and $1.8 \mathrm{~g} / \mathrm{kg}$ in 2090, respectively. No significant future long-term changes in average monthly solar horizontal irradiation were predicted for either time period.

In the second step, the possible impacts of climate change on the energy performance of the existing Hellenic building stock were investigated. The generated climate data were used with available information from about 2500 Hellenic real NR buildings located in different cities around Greece. The available data were used as inputs to the official calculation engine for issuing EPCs, in order to assess the building energy performance and calculate the heating and cooling demand and the buildings' energy use. The calculations were performed using the measured climate data for the present and the model climate data for the future.

Under the baseline scenario RCP8.5, the average heating demand decreased by $29 \%$ and $59 \%$ in the near and the distant future, while the cooling demand increased by $33 \%$ and $72 \%$, respectively. Under the intermediate RCP4.5 scenario, the decrease in heating demand was about $25 \%$ both in the near and the distant future, and the increase in cooling demand was about $30 \%$. It is interesting to note that until mid-century, the differences in demand between the different RCPs are usually very small. On the other hand, the impact of various RCPs differentiates significantly in the distant future.

Looking at the present of the Hellenic NR sector, the heating energy use was estimated at 1.02 Mtoe, while the cooling energy use at 0.73 Mtoe. If the existing NR building stock is not renovated, the cooling demand is expected to increase by $24-28 \%$ for the near future and by $30-66 \%$ for the distant future time periods due to climate change. This may be outweighed in part by a decrease of the heating demand that is expected to reach $22-26 \%$ for the near-future and by $26-52 \%$ for the distant-future.

Even if the number of building energy audits is currently small, the analysis of the available data is an initial step for filling in the gap of knowledge regarding the performance of Hellenic NR buildings taking into account climate change until the end of the century. The process of issuing EPCs constitutes a unique opportunity for collecting information on a national level about the characteristics of buildings and their energy performance. This work presented indicative average results for NR buildings, although it comprises a very heterogeneous sector and energy performance indicators differentiate significantly between various building types. 
Future work will study the energy performance for different non-residential building types. In addition, the model climate data will be exploited for improving the Hellenic building stock model and the assessment of energy conservation measures for short and long term renovation scenarios. It will also be necessary to account for variable primary energy and carbon emissions conversion factors in the coming decades, since the current factors were defined in 2010 not representing the evolution of the energy mix used for power generation. Given the national efforts to increase the share of low-carbon energy sources (mostly renewables) and to abandon lignite power plants by 2028 [59], the new conversion factors are expected to be significantly lower. Apparently, this can have an impact on the projections of the primary energy use for even near-future projections.

Author Contributions: Conceptualization, K.G.D. and C.A.B.; methodology, K.G.D. and C.A.B.; formal analysis, K.G.D., S.K. and C.A.B.; investigation, K.G.D.; data curation, K.G.D., S.K. and K.V.V.; writing—original draft preparation, K.G.D.; writing—review and editing, C.A.B., S.K., K.V.V., C.G., E.G.D. and A.A.A.; visualization, K.G.D. All authors have read and agreed to the published version of the manuscript.

Funding: This research received no external funding.

Institutional Review Board Statement: Not applicable.

Informed Consent Statement: Not applicable.

Data Availability Statement: Not applicable.

Acknowledgments: This research is part of K.G. Droutsa dissertation work at the Department of Physics, University of Patras, Greece. The paper reflects the views only of the authors, who have made every effort to prepare this material for the benefit of the public in light of current and available information. It does not represent the opinion of the European Union or the Hellenic Ministry of Development \& Investments. Neither the European Union and Hellenic institutions and bodies nor the authors may be held responsible for the use which may be made of the information contained therein. The national EPC repository (buildingcert) has been developed and maintained by the Hellenic Ministry of Environment \& Energy (YPEN) in collaboration with the Centre for Renewable Energy Sources. The authors wish to acknowledge YPEN for allowing access to the EPC database. The analysis presented herein does not necessarily reflect the opinion of the Ministry. G. Giannakopoulos and K. V. Varotsos acknowledge support from the program "National Network on Climate Change and its Impacts-Climpact" financed by the Public Investment Program of Greece.

Conflicts of Interest: The authors declare no conflict of interest.

\section{References}

1. Climate Change Committee. A Natural Climate Cycle. What Is Causing Climate Change? Available online: https://www.theccc. org.uk/the-science-of-climate-change/climate-variations-natural-and-human-factors/a-natural-climate-cycle/ (accessed on 10 September 2021).

2. IPCC. Climate Change 2014: Synthesis Report. Contribution of Working Groups I, II and III to the Fifth Assessment Report of the Intergovernmental Panel on Climate Change; Core Writing Team, Pachauri, R.K., Meyer, L.A., Eds.; IPCC: Geneva, Switzerland, 2014; p. 151.

3. Gaffney, O.; Steffen, W. The Anthropocene equation. Anthr. Rev. 2017, 4, 53-61. [CrossRef]

4. The State of the Global Climate 2020, World Meteorological Organization, April 2021. Available online: https:// public.wmo.int/ en/our-mandate/climate/wmo-statement-state-of-global-climate (accessed on 10 September 2021).

5. Anderson, T.R.; Hawkins, E.; Jones, P.D. $\mathrm{CO}_{2}$, the greenhouse effect and global warming: From the pioneering work of Arrhenius and Callendar to today's Earth System Models. Endeavour 2016, 40, 178-187. [CrossRef]

6. IEA. Is Cooling the Future of Heating? International Energy Agency, Paris. 2020. Available online: www.iea.org/commentaries/ is-cooling-the-future-of-heating (accessed on 10 September 2021).

7. EU Energy Statistical Pocketbook and Country Datasheets. Statistical Pocketbook 2021. Available online: https: / / ec.europa.eu/ energy/en/data-analysis/energy-statistical-pocketbook (accessed on 1 October 2021).

8. Wang, H.; Chen, Q. Impact of climate change heating and cooling energy use in buildings in the United States. Energy Build. 2014, 82, 428-436. [CrossRef]

9. Lamberti, G.; Salvadori, G.; Leccese, F.; Fantozzi, F.; Bluyssen, P.M. Advancement on Thermal Comfort in Educational Buildings: Current Issues and Way Forward. Sustainability 2021, 13, 10315. [CrossRef] 
10. Aebischer, B.; Henderson, G.; Jakob, M.; Catenazzi, G. Impact of climate change on thermal comfort, heating and cooling energy demand in Europe. ECEEE Summer Study Proc. 2007, 5, 859-870.

11. Holmes, M.J.; Hacker, J.N. Climate change, thermal comfort and energy: Meeting the design challenges of the 21st century. Energy Build. 2007, 39, 802-814. [CrossRef]

12. Shen, P. Impacts of climate change on U.S. building energy use by using downscaled hourly future weather data. Energy Build. 2017, 134, 61-70. [CrossRef]

13. Wang, L.; Liu, X.; Brown, H. Prediction of the impacts of climate change on energy consumption for a medium-size office building with two climate models. Energy Build. 2017, 157, 218-226. [CrossRef]

14. Verichev, K.; Zamorano, M.; Carpio, M. Effects of climate change on variations in climatic zones and heating energy consumption of residential buildings in the southern Chile. Energy Build. 2020, 215, 109874. [CrossRef]

15. Invidiata, A.; Ghisi, E. Impact of climate change on heating and cooling energy demand in houses in Brazil. Energy Build. 2016, 130, 20-32. [CrossRef]

16. Bezerra, P.; da Silva, F.; Cruz, T.; Mistry, M.; Vasquez-Arroyo, E.; Magalar, L.; De Cian, E.; Lucena, A.F.P.; Schaeffer, R. Impacts of a warmer world on space cooling demand in Brazilian households. Energy Build. 2021, 234, 10696. [CrossRef]

17. Wan, K.K.W.; Li, D.H.W.; Lam, J.C. Assessment of climate change impact on building energy use and mitigation measures in subtropical climates. Energy 2011, 36, 1404-1414. [CrossRef]

18. Chan, A.L.S. Developing future hourly weather files for studying the impact of climate change on building energy performance in Hong Kong. Energy Build. 2011, 43, 2860-2868. [CrossRef]

19. Radhi, H. Evaluating the potential impact of global warming on the UAE residential buildings e a contribution to reduce the $\mathrm{CO}_{2}$ emission. Build. Environ. 2009, 44, 2451-2462. [CrossRef]

20. Huang, K.-T.; Hwang, R.-L. Future trends of residential building cooling energy and passive adaptation measures to counteract climate change: The case of Taiwan. Appl. Energy 2016, 184, 1230-1240. [CrossRef]

21. Chai, J.; Huang, P.; Sun, Y. Investigations of climate change impacts on net-zero energy building lifecycle performance in typical Chinese climate regions. Energy 2019, 185, 176-189. [CrossRef]

22. Karimpour, M.; Belusko, M.; Xing, K.; Boland, J.; Bruno, F. Impact of climate change on the design of energy efficient residential building envelopes. Energy Build. 2015, 87, 142-154. [CrossRef]

23. Dodoo, A.; Ayarkwa, J. Effects of Climate Change for Thermal Comfort and Energy Performance of Residential Buildings in a Sub-Saharan African Climate. Buildings 2019, 9, 215. [CrossRef]

24. Giannakopoulos, C.; Hadjinicolaou, P.; Zerefos, C.; Demosthenous, G. Changing Energy Requirements in the Mediterranean under Changing Climatic Conditions. Energies 2009, 2, 805-815. [CrossRef]

25. Giannakopoulos, C.; Kostopoulou, E.; Varotsos, K.V.; Tziotziou, K.; Plitharas, A. An integrated assessment of climate change impacts for Greece in the near future. Reg. Environ. Chang. 2011, 11, 829-843. [CrossRef]

26. Pezzutto, S.; Toleikyte, A.; De Felice, M. Assessment of the Space Heating and Cooling Market in the EU28: A Comparison between EU15 and EU13 Member States. Int. J. Contemp. Energy 2015, 1, 35-48.

27. Larsen, M.A.D.; Petrović, S.; Radoszynski, A.M.; McKenna, R.; Balyk, O. Climate change impacts on trends and extremes in future heating and cooling demands over Europe. Energy Build. 2020, 226, 110397. [CrossRef]

28. Ciancio, V.; Salata, F.; Falasca, S.; Curci, G.; Golasi, I.; de Wilde, P. Energy demands of buildings in the framework of climate change: An investigation across Europe. Sustain. Cities Soc. 2020, 60, 102213. [CrossRef]

29. Rodríguez, M.V.; Cordero, A.S.; Melgar, S.G.; Márquez, J.M.A. Impact of Global Warming in Subtropical Climate Buildings: Future Trends and Mitigation Strategies. Energies 2020, 13, 6188. [CrossRef]

30. Figueiredo, R.; Nunes, P.; Panão, M.J.N.O.; Brito, M.C. Country residential building stock electricity demand in future climatePortuguese case study. Energy Build. 2020, 209, 109694. [CrossRef]

31. Yang, Y.; Javanroodi, K.; Nik, V.M. Climate change and energy performance of European residential building stocks-A comprehensive impact assessment using climate big data from the coordinated regional climate downscaling experiment. Appl. Energy 2021, 298, 117246. [CrossRef]

32. Barros, V. (Ed.) Climate Change 2014: Impacts, Adaptation, and Vulnerability. Part B: Regional Aspects. Contribution of Working Group II to the Fifth Assessment; Cambridge University Press: Cambridge, UK, 2014.

33. Asimakopoulos, D.A.; Santamouris, M.; Farrou, I.; Laskari, M.; Saliari, M.; Zanis, G.; Giannakidis, G.; Tigas, K.; Kapsomenakis, J.; Douvis, C.; et al. Modelling the energy demand projection of the building sector in Greece in the 21st century. Energy Build. 2012, 49, 488-498. [CrossRef]

34. Cartalis, C.; Synodinou, A.; Proedrou, M.; Tsangrassoulis, A.; Santamouris, M. Modifications in energy demand in urban areas as a result of climate changes: An assessment for the southeast Mediterranean region. Energy Convers. Manag. 2001, 42, $1647-1656$. [CrossRef]

35. Amato, A.D.; Ruth, M.; Kirshen, P.; Horwitz, J. Regional energy demand responses to climate change: Methodology and application to the commonwealth of Massachusetts. Clim. Chang. 2005, 71, 175-201. [CrossRef]

36. Wan, K.K.W.; Li, D.H.W.; Liu, D.; Lam, J.C. Future trends of building heating and cooling loads and energy consumption in different climates. Build. Environ. 2011, 46, 223-234. [CrossRef]

37. Clarke, L.; Eom, J.; Marten, E.H.; Horowitz, R.; Kyle, P.; Link, R.; Mignone, B.K.; Mundra, A.; Zhou, Y. Effects of long-term climate change on global building energy expenditures. Energy Econ. 2018, 72, 667-677. [CrossRef] 
38. Zhou, Y.; Eom, J.; Clarke, L. The effect of global climate change, population distribution, and climate mitigation on building energy use in the U.S. and China. Clim. Chang. 2013, 119, 979-992. [CrossRef]

39. Raju, K.S.; Kumar, D.N. Review of approaches for selection and ensembling of GCMs. J. Water Clim. Chang. 2020, 11, 577-599. [CrossRef]

40. Meinshausen, M.; Smith, S.J.; Calvin, K.; Daniel, J.S.; Kainuma, M.L.T.; Lamarque, J.-F.; Matsumoto, K.; Montzka, S.A.; Raper, S.C.B.; Riahi, K.; et al. The RCP greenhouse gas concentrations and their extensions from 1765 to 2300. Clim. Chang. 2011, 109, 213. [CrossRef]

41. Van Vuuren, D.P.; Edmonds, J.; Kainuma, M.; Riahi, K.; Thomson, A.; Hibbard, K.; Hurtt, G.C.; Kram, T.; Krey, V.; Lamarque, J.-F.; et al. The representative concentration pathways: An overview. Clim. Chang. 2011, 109, 5. [CrossRef]

42. United Nations Framework Convention on Climate Change (UNFCCC). Available online: https://unfccc.int/files/adaptation/ application/pdf/1.26_smhi_doescher.pdf (accessed on 10 September 2021).

43. Melo, C.; Melo, O. Spatio-Temporal; Inverse Distance Weighting and Radial Basis Functions with Distance-Based Regression, Package Geosptdb, 2015. Available online: https://cran.r-project.org/web/packages/geosptdb/geosptdb.pdf (accessed on 10 September 2021).

44. Panagea, I.S.; Tsanis, I.K.; Koutroulis, A.G.; Grillakis, M.G. Climate change impact on photovoltaic energy output: The case of Greece. Adv. Meteorol. 2014, 2014, 264506. [CrossRef]

45. Balaras, C.A.; Dascalaki, E.G.; Droutsa, K.G.; Kontoyiannidis, S.; Guruz, R.; Gudnason, G. Energy \& Other Key Performance Indicators for Buildings-Examples for Hellenic Buildings. Glob. J. Energy Technol. Res. Updates 2014, 1, 71-89.

46. Droutsa, K.G.; Balaras, C.A.; Dascalaki, E.G.; Kontoyiannidis, S.; Argiriou, A.A. Energy Use Intensities for Asset Rating of Hellenic Non-Residential Buildings. Glob. J. Energy Technol. Res. Updates 2018, 5, 19-36.

47. Dascalaki, E.G.; Balaras, C.A.; Gaglia, A.G.; Droutsa, K.G.; Kontoyiannidis, S. Energy performance of buildings-EPBD in Greece. Energy Policy 2012, 45, 469-477. [CrossRef]

48. Sandberg, N.H.; Sartori, I.; Heidrich, O.; Dawson, R.; Dascalaki, E.; Dimitriou, S.; Vimm-r, T.; Filippidou, F.; Stegnar, G.; Šijanec Zavrl, M.; et al. Dynamic building stock modeling: Application to 11 European countries to support the energy efficiency and retrofit ambitions of the EU. Energy Build. 2016, 132, 26-38. [CrossRef]

49. Popke, D.; Stevens, B.; Voigt, A. Climate and climate change in a radiative-convective equilibrium version of ECHAM6. J. Adv. Model. Earth Syst. 2013, 5, 1-14. [CrossRef]

50. Jacob, D.; Teichmann, C.; Sobolowski, S.; Katragkou, E.; Anders, I.; Belda, M.; Benestad, R.; Boberg, F.; Buonomo, E.; Cardoso, R.M.; et al. Regional climate downscaling over Europe: Perspectives from the EURO-CORDEX community. Reg. Environ. Chang. 2020, 20, 51. [CrossRef]

51. Report on Quality of Statistical Data from EPCs (In Greek). Available online: http://ypeka.gr/Default.aspx?tabid=907\& language $=\mathrm{el}-\mathrm{GR}$ (accessed on 10 September 2021).

52. Humidity-The Second Pillar of Climate Change. Available online: www.metoffice.gov.uk/about-us/press-office/news/weatherand-climate/2020/scientists-investigate-humidity---the-second-pillar-of-climate-change (accessed on 10 September 2021).

53. Bartók, B. Review of Surface Solar Radiation Projections in Bias-Corrected Euro-Cordex Regional Climate Models, Annals of West University of Timisoara. Physics 2018, 60, 3-13.

54. Jerez, S.; Thais, F.; Tobin, I.; Wild, M.; Colette, A.; Yiou, P.; Vautard, R. The CLIMIX model: A tool to create and evaluate spatially-resolved scenarios of photovoltaic and wind power development. Renew. Sustain. Energy Rev. 2014, 42, 1-15. [CrossRef]

55. Wild, M.; Folini, D.; Henschel, F.; Fischer, N.; Müller, B. Projections of long-term changes in solar radiation based on CMIP5 climate models and their influence on energy yields of photovoltaic systems. Sol. Energy 2015, 116, 12-24. [CrossRef]

56. Bartók, B.; Wild, M.; Folini, D.; Lüthi, D.; Kotlarski, S.; Schär, C.; Vautard, R.; Jerez, S.; Imecs, Z. Projected changes in surface solar radiation in CMIP5 global climate models and in EURO-CORDEX regional climate models for Europe. Clim. Dyn. 2017, 49, 2665-2683. [CrossRef]

57. IPCC. Climate Change 2013: The Physical Science Basis. Contribution of Working Group I to the Fifth Assessment Report of the Intergovernmental Panel on Climate Change; Stocker, T.F., Qin, D., Plattner, G.-K., Tignor, M., Allen, S.K., Boschung, J., Nauels, A., Xia, Y., Bex, V., Midgley, P.M., Eds.; Cambridge University Press: Cambridge, UK; New York, NY, USA, 2014; 1535p.

58. Jacob, D.; Petersen, J.; Eggert, B.; Alias, A.; Christensen, O.B.; Bouwer, L.M.; Braun, A.; Colette, A.; Déqué, M.; Georgievski, G.; et al. EURO-CORDEX: New high-resolution climate change projections for European impact research. Reg. Environ. Chang. 2014, 14, 563-578. [CrossRef]

59. National Plan for Energy and Climate (In Greek). Available online: www.opengov.gr/minenv/?p=10155 (accessed on 10 September 2021). 